Research Article

\title{
Evaluation of socio-demographic factors and attempted suicides in the elderly
} İntihar girişiminde bulunan yaşlilarda sosyo-demografik etmenlerin değerlendirilmesi

\author{
Sinan Yenal ${ }^{\mathbf{a}}$, Ahu Pakdemirli $^{\mathbf{b}}$, Basak Bayram $^{\mathbf{c}}$, (D) Ne Direk Tecirli $^{\mathbf{d}}$ \\ ${ }^{\text {a }}$ Department of Paramedics, Health Care Services Vocational School, Dokuz Eylul University, Izmir, Turkey \\ Department of Physiology, Gulhane School of Medicine, University of Health Sciences, Ankara, Turkey \\ c Department of Emergency, School of Medicine, Dokuz Eylul University, Izmir, Turkey \\ Department of Psychiatry, School of Medicine, Dokuz Eylul University, Izmir, Turkey
}

d

\begin{abstract}
Introduction: The aim of this study is to reveal the socio-demographic and certain clinical characteristics of elderly patients admitted to the emergency department after a suicide attempt.

Methods: This is a cross-sectional study. The universe of the study consisted of 96 patients aged 60 and over who were admitted to emergency department of Izmir Dokuz Eylul University Hospital between 2015-2019 due to a suicide attempt. Information for the study was obtained by retrospectively scanning the files of the patients.

Results: Mean age of the 96 patients included in the study was $68.22 \pm 9.45$ years. The most common suicide method among the patients was drug overdose (n: $59,61.45 \%$ ). It was found that $45.05 \%$ of the patients who attempted suicide had a known psychiatric diagnosis (n:41). The suicide rate of women $(\mathrm{n}: 42,43.75 \%)$ who were primary school graduates $(\mathrm{p}=0.026)$, had a known psychiatric illness ( $\mathrm{p}=0.001)$, continuously used drugs $(\mathrm{p}=0.002)$ and used antidepressants $(\mathrm{p}<0.001)$ was significantly higher compared to men $(\mathrm{n}: 54,56.25 \%)$.

Conclusion: Being a primary school graduate, having a psychiatric illness, and using antidepressants increase suicide rates in women. It was suggested that this group of patients with suicidal tendencies should be treated with more care in emergency department.

Keywords: Emergency department, suicide, aged patient, risk factors
\end{abstract}

\section{$\ddot{O} z$}

Giriş: İntihar girişimi nedeni ile acil servise başvuran yaşlı hastaların sosyo-demografik ve belirli klinik özelliklerini ortaya koymaktır.

Yöntem: Kesitsel tipte planlanmış bir araştırmadır. Çalışmanın evreni; İzmir Dokuz Eylül Üniversite Hastanesi acil servisine, $2015-2019$ yılları arası, intihar girişimi nedeniyle başvuran 60 yaş ve üzeri toplam 96 hastadan oluşmuştur. Çalışma için bilgiler hastaların dosyaları geriye dönük olarak taranarak elde edilmiştir.

Bulgular: Çalışmaya alınan toplam 96 hastanın yaş ortalaması 68,22 $\pm 9,45$ olarak hesaplanmıştır. İntihar yöntemi olarak hastalar en çok ilaç içme yöntemini (n:59, \%61,45) kullandıkları görülmüştür. İntihar girişiminde bulunan hastaların \%45,05'inin bilinen bir psikiyatrik hastalık tanısı olduğu bulunmuştur ( $\mathrm{n}: 41$ ). İlkokul mezunu olan ( $\mathrm{p}=0,026)$, bilinen bir psikiyatrik hastalığı bulunan ( $\mathrm{p}=0,001)$, sürekli ilaç kullanan ( $\mathrm{p}=0,002)$ ve antidepresan kullanan $(\mathrm{p}<0,001)$ kadınların (n:42, \%43,75) intihar oranı erkeklere (n:54, \%56,25) göre istatistiksel olarak anlamlı derecede yüksek bulunmuştur.

Sonuç: Kadınlarda, ilkokul mezunu olmak, psikiyatrik hastalığı bulunmak ve antidepresan kullanmanın intihar oranını arttırdığı görülmüştür. İntihara meyilli bu grup hastalar için acil servislerde daha özenli davranılması gerektiği önerilmiştir.

Anahtar Kelimeler: Acil servis, intihar, yaşlı hasta, risk faktörleri

\begin{tabular}{|c|c|c|c|c|}
\hline Received & Accepted & Published Online & Corresponding Author & E-mail \\
\hline October 1, 2020 & March 16, 2021 & April 3, 2021 & Sinan Yenal, PhD & sinan.yenal@ @eu.edu.tr \\
\hline Correspondence & \multicolumn{2}{|l|}{$\begin{array}{l}\text { Dr. Sinan Yenal. Dokuz Eylül University, Health Care Services Vocational School, Department of } \\
\text { Paramedics, Balcova, Izmir, Turkey }\end{array}$} \\
\hline
\end{tabular}




\section{Introduction}

Every death event that occurs directly or indirectly as a result of a positive or negative act knowingly performed that it will result in death is defined as suicide [1]. Suicide is a serious and global public health problem. More people die from suicide from malaria, breast cancer, war and murder. Suicide is one of the top 20 causes of death worldwide, with nearly 800,000 deaths each year. Suicides and suicide attempts are important because they have a ripple effect affecting families, friends, colleagues, communities and societies [2]. Turkish Statistical Institute (TUIK) data in 2019 shows that 3,406 people committed suicide and crude suicide rate is calculated to be 4.12/100,000 [3].

One of the most important factors affecting the suicide rate in a society is age, and suicide rate in people aged 60 and over increases with age [4]. In almost all regions of the world, the highest suicide rate for both men and women is seen in people aged 70 and over [5]. In this age group, frequent life events such as retirement, loss of spouse/divorce, death of friends and family, isolation, medical diagnosis and functional impairment put the elderly at higher risk of suicidal behavior [6]. Among the main risk factors of elderly individuals attempting suicide are male gender, loss of a partner/spouse or loved one, living alone, weak family ties, being a minority, loss of economic and social status as a result of aging, and the presence of physical and mental illness [7].

According to a World Health Organization (WHO) report, crude suicide rate between 50-70 years of age is 20.1/100,000 in the United States, 50.1/100,000 in Korea, 30.1/100,000 in Japan, 20.0/100,000 in India, and 4.2/100,000 in Turkey [5]. According to 2018 Turkish Statistical Institute data, $17.2 \%$ of all suicide attempts were made by people aged 60 or older [3].

A strong relationship has been found between suicidal behavior and psychopathology, especially major depressive disorder, in elderly individuals [8]. Although elderly individuals with depression expressed less suicidal thoughts, the rate of completed suicide was found to be higher among the elderly [9].

Hospital emergency departments (ED) are often the places where suicide attempters apply first, are evaluated and treated. For this reason, it is important to know the demographic characteristics of the cases applying to the ED after a suicide attempt, and the treatments and psychiatric support provided to these people in ED [10].

The aim of this study is to reveal the socio-demographic and certain clinical characteristics of elderly patients admitted to the ED after a suicide attempt.

\section{Methods}

\section{Study participants}

The population of this cross-sectional study consisted of patients aged 60 and over who were admitted to the ED of Izmir Dokuz Eylul University Hospital between 01.01.2015 and 31.12.2019 (five years) after a suicide attempt. Sample selection was not conducted, and the target was to reach the entire study population. Between the specified dates, a total of 96 patients admitted to the ED due to suicide, and all of them were included in the study.

\section{Study procedures}

The patients who had been admitted due to suicide attempt were determined by a retrospective search through the ICD-10 codes between X60 and X84 between the dates determined by the hospital data processing system Probel-HBYS program. Archive files of the determined patients were scanned retrospectively, and the information was recorded in the study form. The study form includes information such as gender, age, with whom the patients lived, marital status, educational status, method of suicide, whether there was a previously diagnosed psychiatric disease, presence of suicide attempt in the past, and information on continuously used drugs.

\section{Statistical analysis}

The data were evaluated with the "SPSS (SPSS Inc., Chicago, IL, USA) for Windows 18.0" program. Descriptive tables were used to present the variables. The "Chi-square Test" was used to compare the gender and socio-demographic characteristics of the patients who were admitted to the ED after a suicide attempt.

\section{Ethical approval}

This study was approved by the Non-Interventional Research Ethics Committee of Dokuz Eylul University with the decision number 2019/31-37, protocol number 5123-GOA, dated 16.12.2019.

\section{Results}

Between the dates of data collection, a total of 96 patients aged 60 and over were admitted to the ED after a suicide attempt. The mean age of the patients was $68.22 \pm 9.45$ years (range 60-94 years). The socio-demographic characteristics of the patients is presented in Table 1.

Table 2 shows the information about suicide attempts of patients admitted to the ED. The most common method of suicide was drug overdose (n: $59,61.45 \%)$. It was found that 41 patients $(45.05 \%)$ who attempted suicide had a known diagnosis of psychiatric illness and majority of these diagnoses were depression (n: $33,80.48 \%$ ). 
Table 1. Socio-demographic characteristics of the patients (n:96)

\begin{tabular}{|c|c|c|}
\hline & $\mathbf{n}$ & $\% *$ \\
\hline \multicolumn{3}{|l|}{ Gender: } \\
\hline Female & 42 & 43.75 \\
\hline Male & 54 & 56.25 \\
\hline \multicolumn{3}{|l|}{ Age group: } \\
\hline $60-74$ years & 73 & 76.04 \\
\hline $75-84$ years & 15 & 15.62 \\
\hline 85 and above & 8 & 8.34 \\
\hline \multicolumn{3}{|l|}{ Marital status: } \\
\hline Married & 47 & 51.64 \\
\hline $\begin{array}{l}\text { Not married (widowed, } \\
\text { divorced, single) }\end{array}$ & 44 & 48.36 \\
\hline \multicolumn{3}{|l|}{ Living accommodation: } \\
\hline With family & 44 & 51.16 \\
\hline Alone & 22 & 25.58 \\
\hline With children & 15 & 17.44 \\
\hline Nursing home & 5 & 5.82 \\
\hline \multicolumn{3}{|c|}{ Presence of chronic disease: } \\
\hline Yes & 37 & 40.65 \\
\hline No & 54 & 59.35 \\
\hline \multicolumn{3}{|c|}{ Chronic disease diagnosis: (n:37) } \\
\hline Diabetes & 13 & $35.13 * *$ \\
\hline Hypertension & 12 & $32.43 * *$ \\
\hline Cancer & 8 & $21.62 * *$ \\
\hline Dementia & 5 & $13.51 * *$ \\
\hline Heart Failure & 3 & $8.10 * *$ \\
\hline Cerebrovascular dis. & 3 & $8.10 * *$ \\
\hline Other & 3 & $8.10 * *$ \\
\hline \multicolumn{3}{|l|}{ Educational Status: } \\
\hline Primary school & 26 & 50.00 \\
\hline High school & 12 & 23.07 \\
\hline University & 14 & 26.93 \\
\hline
\end{tabular}

Table 2. Information on suicide attempt of patients evaluated in the ED (n:96).

\begin{tabular}{|c|c|c|}
\hline & $\mathbf{n}$ & $\% *$ \\
\hline \multicolumn{3}{|l|}{ Method: } \\
\hline Drug Overdose & 59 & 61.45 \\
\hline Chemical Agent & 15 & 15.62 \\
\hline Wounding & 10 & 10.41 \\
\hline Jumping from height & 9 & 9.37 \\
\hline Other & 3 & 3.15 \\
\hline \multicolumn{3}{|l|}{ Previous history of suicide: } \\
\hline Yes & 14 & 15.38 \\
\hline No & 77 & 84.62 \\
\hline \multicolumn{3}{|l|}{ Known psychiatric disease: } \\
\hline Yes & 41 & 45.05 \\
\hline No & 50 & 54.95 \\
\hline \multicolumn{3}{|l|}{ Psychiatric diagnosis: $(\mathrm{n}: 41)$} \\
\hline Depression & 33 & 80.48 \\
\hline Other & 8 & 19.52 \\
\hline \multicolumn{3}{|l|}{ Continuous medication use: } \\
\hline Yes & 51 & 56.04 \\
\hline No & 40 & 43.96 \\
\hline \multicolumn{3}{|l|}{$\begin{array}{l}\text { Continuously used medications: } \\
(\mathrm{n}: 51)\end{array}$} \\
\hline Antidepressant & 39 & $76.47 * *$ \\
\hline Antipsychotic & 12 & $23.52 * *$ \\
\hline Anxiolytic & 9 & $17.64 * *$ \\
\hline Other & 13 & $25.49 * *$ \\
\hline \multicolumn{3}{|l|}{ Psychiatric consultation diagnosis: } \\
\hline Depression & 58 & 65.90 \\
\hline Impulsive attempt & 21 & 23.86 \\
\hline Other & 9 & 10.24 \\
\hline \multicolumn{3}{|l|}{ ED*** outcome: } \\
\hline Discharge & 80 & 83.33 \\
\hline Admission to the psychiatric ward & 10 & 10.41 \\
\hline Admission to the intensive care unit & 2 & 2.08 \\
\hline $\begin{array}{l}\text { Admission to the internal } \\
\text { medicine service }\end{array}$ & 1 & 1.04 \\
\hline Dead & 3 & 3.14 \\
\hline
\end{tabular}

Table 3 shows the comparison of gender and socio-demographic characteristics of the patients admitted to the ED after a suicide attempt. The suicide rate of women who were primary school graduates $(\mathrm{p}=0.026$ ), had a known psychiatric illness ( $\mathrm{p}=0.001$ ), continuously used drugs $(\mathrm{p}=0.002)$ and used antidepressants $(\mathrm{p}<0.001)$ was significantly higher compared to men. 
Table 3. Comparison of gender and socio-demographic characteristics of patients admitted to the ED after a suicide attempt (n:96).

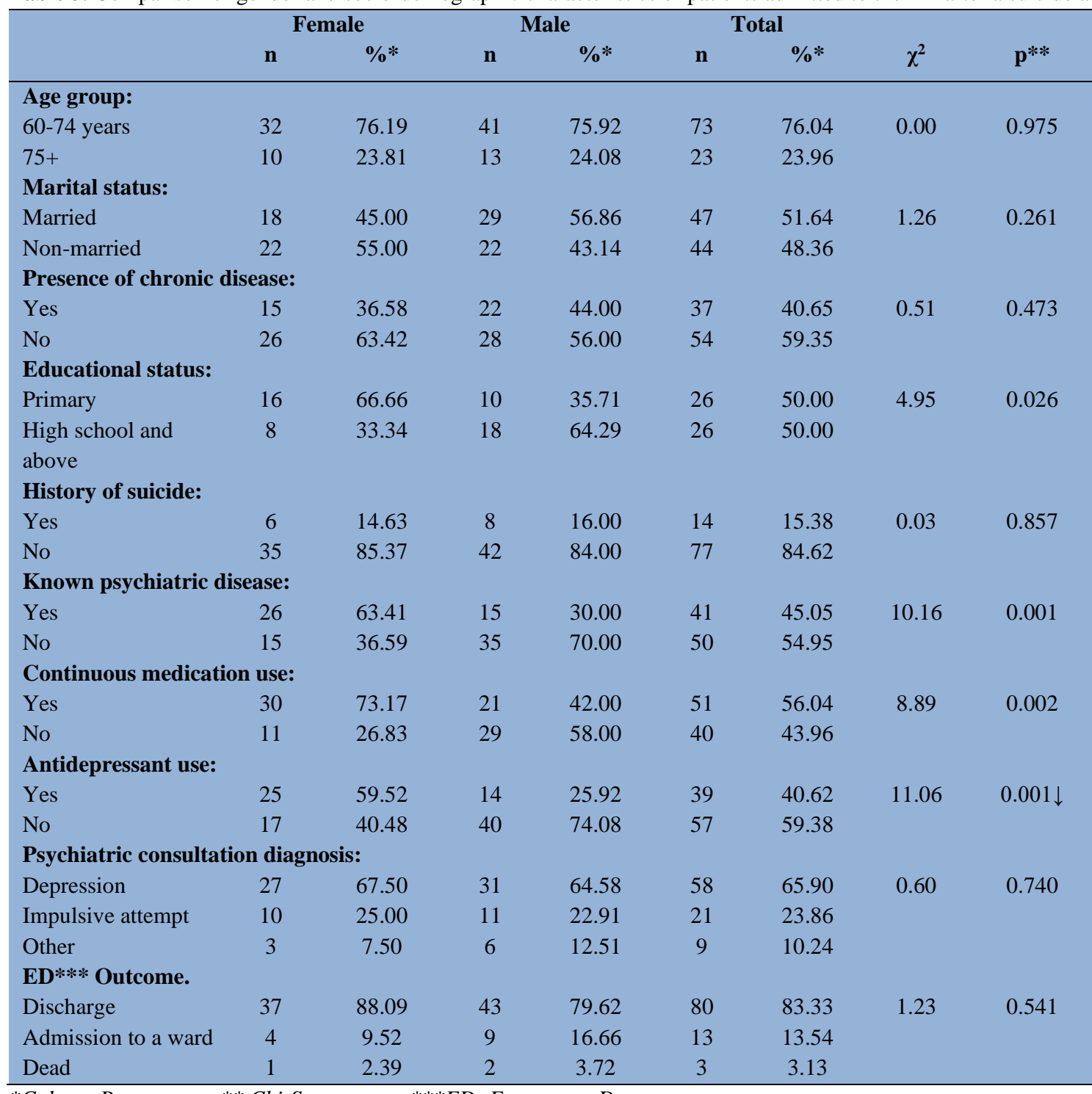

*Column Percentage ** Chi-Square test ***ED: Emergency Department

\section{Discussion}

This study is valuable as it evaluates socio-demographic characteristics and suicide attempts by retrospectively examining the files of patients who were admitted to the ED after a suicide attempt. In the present study, suicide rate was found to be significantly higher in women compared to men. Being a primary school graduate, having a psychiatric illness, continuous medication use and antidepressant use significantly increased suicide rate in women compared to men.

The most common suicide method in the present study was drug overdose (61.45\%). In a similar study conducted by Gokcelli et al. in the province of Izmir, the authors stated that $74.6 \%$ of the elderly patients took drugs as a method of suicide [9]. Yigit et al. conducted a study in the ED to cover all age groups and showed that method of suicide was drug overdose in $88 \%$ of the cases [10]. Similarly, in the study of Atli et al., method of suicide was drug overdose in $93.4 \%$ of the cases [11]. The ratio of drug overdose as a suicide method was $86.5 \%$ in a Chinese study by Zhao et al. and $57.2 \%$ in a study conducted by De Leo et al. in 16 European cities [12,13]. As in all age groups, it is seen that the most common suicide method in the elderly is drug overdose.

It was observed that elderly women who were primary school graduates had a higher suicide rate compared to men $(p=0.026)$. In a study by Terranova et al. conducted in Italy, it was shown that education and suicide were negatively correlated [14]. Kadioglu's study showed that $41.3 \%$ of those who committed suicide were primary school graduates [15]. This ratio was $47.1 \%$ in Atli et al's study, $49 \%$ in Sevik et al's study, and $58.1 \%$ in Gokceli et al.'s study $[9,11,16]$. The inverse relationship between education level and suicide was also shown in this study.

Psychiatric diseases play an important role in older adults committing suicide [17]. In the present study, it was found that women with a known psychiatric disease were more likely to commit suicide. Zhao et al. stated that psychiatric diseases play an effective role in suicide [12]. In the study they conducted in South Korea, Lim et al. reported that $28.4 \%$ of the elderly who committed suicide had a known psychiatric disease [18]. Suominen et al. stated that depression is an important risk factor for suicides, but the presence of depression is most often noticed after a suicide attempt and that the elderly should be monitored for depression [19]. Vanderhorat et al. showed that depression and suicidal ideation were related [20]. Gokcelli et al. found that $63.5 \%$ of the patients who attempted suicide had a known psychiatric disease and $40.3 \%$ of these patients were 
diagnosed with major depression [9]. Sevik et al. found that the rate of having a known psychiatric disease in patients who committed suicide was $40 \%$ and that $31 \%$ of these patients were diagnosed with depression [16]. $18.2 \%$ and $29 \%$ of the patients had a known psychiatric disease in the studies conducted by Kadioglu and by Yigit et al., respectively, and Yigit et al. also reported that $46 \%$ of these patients were diagnosed with depression $[10,15]$. The results of the present study are generally consistent with other studies.

Since $45.05 \%$ of the patients included in the study had a psychiatric disease and $80.48 \%$ of these patients were diagnosed with depression, the use of antidepressants was high (40.62\%) as a natural consequence. In their study, Juurlink et al. found that the risk of suicide increased by 4.8 times in the first month of taking antidepressants [21]. Makris et al. conducted a study in Sweden and observed a high suicide rate in people using antidepressants [22]. There are also studies showing that the use of antidepressants reduces the risk of suicide. Carlsten et al. showed that there was no relationship between antidepressant use and suicide risk [23]. The results of the analyzes conducted by the US, FDA (Food and Drug Administration) reveal that the use of antidepressants significantly reduced the risk of suicidal ideation and behavior in geriatric patients over 65 years of age (OR $=0.37,95 \% \mathrm{CI}, 0.18-0.76)$ [24]. Conwell et al. reported that depression is the most evident and modifiable risk factor for suicide, and that effective antidepressant treatment is the best way to reduce suicide rates [25]. This study showed that women using antidepressants are more likely to attempt suicide.

\section{Limitations}

There are certain limitations of the present study. The most important limitation is the retrospective nature of the study. Due to missing information in patient files requested for research, some data were evaluated with a low number of patients. Another limitation is the deficiencies that may arise as a result of some files being skipped during the initial review or false information accidentally processed in the patient files.

\section{Conclusion}

The most common method of suicide in the elderly population is drug overdose. Being a primary school graduate, having a psychiatric illness, and using antidepressants increase suicide rates in women. It was suggested that this group of patients with suicidal tendencies should be treated with more care in ED.

Conflict of interest: The authors declare that they have no conflict of interest.

\begin{tabular}{|c|r|l|}
\hline \multicolumn{2}{|c|}{ Author Contributions } & \multicolumn{1}{c|}{ Author Initials } \\
\hline SCD & Study Conception and Design & SY, AP, BB, NDT \\
\hline AD & Acquisition of Data & SY, BB, \\
\hline AID & Analysis and Interpretation of Data & SY, AP, BB \\
\hline DM & Drafting of Manuscript & SY, AP, NDT \\
\hline CR & Critical Revision & SY, BB, NDT \\
\hline
\end{tabular}

\section{Financial support: None}

Acknowledgements: We thank all participated in the study.

\section{References}

1. Durkheim E. Suicide. Ozankaya O. (Translated by) 1. Edi, Ankara: Imge; 1992:25.

2. World health organization. Suicide in the world: Global health estimates 2019 [Internet]. Available at: https://www.who.int/publicationsdetail/suicide-in-the-world (Access Date: September 09, 2020).

3. Turkey statistical agency (TUIK). Basic statistics [Internet]. Available at: http://www.tuik.gov.tr/UstMenu.do?metod=temelist (Access Date: September 09, 2020).

4. Shah A, Bhat R, Escudero SZ, DeLeo D, Erlangsen A. Suicide rates in five-year age-bands after the age of 60 years: the international landscape. Aging Ment Health. 2016;20(2):131-8. https://doi.org/10.1080/13607863.2015.1055552

5. World Health Organization. Preventing suicide: a global imperative 2014 [Internet]. Available at: https://www.who.int/mental_health/suicideprevention/world report 2014/en/ (Access Date: September 09, 2020).

6. Santos J, Martins S, Azevedo LF, Fernandes L. Pain as a risk factor for suicidal behavior in older adults: a systematic review. Arch Gerontol Geriatr. 2020;87(2):104000. https://doi.org/10.1016/j.archger.2019.104000

7. Saraiva CB, Peixot B, Sampaio D. [Elder and suicide behavior. Suicide and self-injurious behavior: from concepts to clinical practice] (in Portuguese). First Edi, Lisbon: Lidel;2014:263-4.

8. Conwell Y, Duberstein PR, Cox C, Herrmann JH, Forbes NT, Caine ED. Relationships of age and axis I diagnoses in victims of completed suicide: a psychological autopsy study. Am J Psychiatry 1996;153(8):1001-8. https://doi.org/10.1176/ajp.153.8.1001

9. Gokcelli DK, Tasar PT, Akcam NO, Sahin S, Akarca FK, Aktas EO, et al. Evaluation of attempted older adults' suicides admitted to a university hospital emergency department: Izmir study. Asian J Psychiatr 2017;30(6):196-9. http://dx.doi.org/10.1016/j.ajp.2017.10.002

10. Yigit O, Soyuncu S, Berk Y. [Who are the suicide attempters? a view from an emergency department] (in Turkish). New Symposium J 2010;48(2):122-8.

11. Atli A, Uysal C, Kaya CM, Bulut M, Gunes M, Karababa IF, et al. [Assessment of admission to the emergency department due to suicide attempt: Sanliurfa sample] (in Turkish). J Mood Disord 2014;4(3):110-4. http://dx.doi.org/10.5455/jmood.20131230123128 
12. Zhao C, Dank X, Su X, Bai J, Ma L. Epidemiology of suicide and associated socio-demographic factors in emergency department patients in 7 general hospitals in northwestern China. Med Sci Monit 2015;21:2743-9. https://doi.org/10.12659/msm.894819

13. De Leo D, Padoani W, Scocco P, Lie D, Bille-Brahe U, Arensman E, et al. Attempted and completed suicide in older subjects: results from the WHO/ EURO multicentre study of suicidal behaviour. Int J Geriatr Psychiatry. 2001;6(3):300-10. https://doi.org/10.1002/gps.337

14. Terranova C, Cardin F, Bruttocao A, Militello C. Analysis of suicide in the elderly in Italy. Risk factors and prevention of suicidal behavior. Aging Clin Exp Res 2012;24(3):20-3. https://pubmed.ncbi.nlm.nih.gov/23160501/

15. Kadioglu E. Assessment of suicidal cases among emergency department applicants Kutahya Evliya Çelebi Training and Research Hospital experience. Eurasian J Emerg Med. 2020;19(2):111-4. http://dx.doi.org/10.4274/eajem.galenos.2017.29484

16. Sevik AE, Ozcan H, Uysal E. [Analyzing suicide attempts: risk factors and follow up] (in Turkish). J Clin Psychiatry 2012;15(4):218-25.

17. Conejero I, Olié E, Courtet P, Calati R. Suicide in older adults: current perspectives. Clin Interv Aging. 2018;13:691-9. http://dx.doi.org/10.2147/CIA.S130670

18. Lim JY, Lee DH. Characteristics of drugs ingested for suicide attempts in the elderly. J Korean Med Sci. 2018;12;33(11):e86. https://doi.org/10.3346/jkms.2018.33.e86

19. Suominen K, Isometsä E, Lönnqvist J. Elderly suicide attempters with depression are often diagnosed only after the attempt. Int J Geriatr Psychiatry. 2004;19(1):35-40. https://doi.org/10.1002/gps.1031

20. Vanderhorst RK, McLaren S. Social relationships as predictors of depression and suicidal ideation in older adults. Aging Ment Health. 2005;9(6):517-25. https://doi.org/10.1002/da.22759

21. Juurlink DN, Pharm MMM, Kopp A, Redelmeier DA. The risk of suicide with selective serotonin reuptake inhibitors in the elderly. Am J Psychiatry. 2006; 163(5):813-21. https://doi.org/10.1176/ajp.2006.163.5.813

22. Makris GD, Reutfors J, Osby U, Isacsson G, Frangakis C, Ekbom A, et al. Suicide seasonality and antidepressants: a register-based study in Sweden. Acta Psychiatr Scand. 2013;127(2):117-25. https://doi.org/10.1111/j.1600-0447.2012.01891.x

23. Carlsten A, Waern M. Are sedatives and hypnotics associated with increased suicide risk of suicide in the elderly? BMC Geriatrics. 2009;9(20):1-6. https://doi.org/10.1186/1471-2318-9-20

24. FDA U.S. Food and drug administration clinical review: relationship between antidepressant drugs and suicidality in adults. [Internet]. Available at: http://www.fda.gov/ohrms/dockets/ac/06/briefing/2006-4272b1-01 FDA.pdf (Access Date: September 09, 2020).

25. Conwell Y, Duberstein PR, Caine ED. Risk factors for suicide in later life. Biol. Psychiatry. 2002;52(3):193-204. https://doi.org/10.1016/s0006-3223(02)01347-1 